\title{
Construction Projects Delay and Their Antidotes: The Case of Ethiopian Construction Sector
}

\author{
Zinabu Tebeje Zewdu \\ Faculty of Business and Economics, Unity University, Addis Ababa, Ethiopia
}

\section{Email address:}

Zinabut@yahoo.com

\section{To cite this article:}

Zinabu Tebeje Zewdu. Construction Projects Delay and Their Antidotes: The Case of Ethiopian Construction Sector. International Journal of Business and Economics Research. Vol. 5, No. 4, 2016, pp. 113-122. doi: 10.11648/j.ijber.20160504.16

Received: December 21, 2015; Accepted: January 26, 2016; Published: August 6, 2016

\begin{abstract}
The Ethiopian construction sector has shown a remarkable growth and is given high prominence. However, several defects are being noted in the sector that need immediate action. The current study was conducted to access the level of techniques and software packages used for project time control; to identify factors affecting delay in construction projects and to recommend possible mitigation measures. The study adopts quantitative and qualitative methods with the help of primary and secondary data. Primary data was collected using self-administered questionnaires on 140 respondents and key informant interviews with ten experienced practitioners in the construction sector. Secondary data was collected through reviewing of related materials. Analysis of the quantitative data was made using SPSS version 20. The study revealed low level application of techniques and software packages for project planning and time control. It also identified top five delay factors. The study suggested that current project planning and time control can be improved by adopting the right tools, assigning the appropriate staff. The study implied that delay factors can be managed by proactive planning on alternative resources, appropriate allocation of resources, application of timely knowledge based decisions, and adoption and application of suitable methodologies and resources at the right place and time coupled with provision of continuous trainings for the staff.
\end{abstract}

Keywords: Delay, Project Management, Project Control, Project Success, Schedule

\section{Introduction}

Timely and with budget completion of a construction project is frequently seen as a major criterion of project success by clients, contractors, consultants and related stakeholders (Luka and Muhammad, 2014; Ibrahim and Nabil, 2013; Abadir, 2011; Chabota et al., 2008). The primary challenge of a project is the handling of constraints to meet the desired goal where one aims to honor the primary constraints of time and budget to produce quality result (ECIDP, 2014; Warszawski, 1996).

Ethiopia is the fastest-growing, non-oil driven economy among African countries. The country has showed a remarkable growth over the past ten years with average annual growth GDP of $10.9 \%$ (UNDP, 2014). Recently, the contribution of the industry sector (which is $21.2 \%$ ) and particularly that of the construction sector to the national economy is given high prominence and is mainly driven by the energetic performance of the construction sub-sector
(ECIDP, 2014; UNDP, 2014). Despite the construction sector has high importance, several defects are being noted in the sector that require immediate action (ECIDP, 2014; Nega, 2008). One significant problem is significant delay of infrastructure and construction projects which can hold back or impair planned economic development (ECIDP, 2014; LiYin et al, 2006).

The rationale for conducting the current study comes from the fact that most studies conducted in the areas of projects delay in construction sector in Ethiopia are more than 5 years old and the booming of the construction industry needs upto-date investigation (Ali and Kamaruzzaman, 2010; Azhar et al., 2008; Chabota et al., 2008; Nega, 2008). Besides, most of the studies are conducted outside Ethiopia and are limited to part of the civil construction like road or building. While some of the surveys are small size which might affect the reliability of the result, others are conducted only in one sector of construction with only either consultant or contractor perspectives. Moreover, available studies do not include the degree of difficulty and summarize accordingly 
the potential solutions (Luka and Muhammad, 2014; Ibrahim and Nabil, 2013; Mahamid and Amund, 2012; Abadir, 2011; Ali and Kamaruzzaman, 2010; Olawale and Sun, 2010; Azhar et al., 2008; Chabota et al., 2008). Hence, the current study aimed to access the level of techniques and software packages used for project time control, to identify factors affecting delay in construction projects in Ethiopia from various stakeholders (consultant, contractor, client and other engineering professionals) perspective and to identify possible mitigation measures.

\section{Literature Review}

\subsection{Time Variation and Mitigation Measures}

Schedule delay can be defined as a discrepancy where actual completion of the project exceeds the planed period according to the contract (Chabota et al., 2008). According to Larry (2002), project schedule is characterized by client urgent demand of project completion, client preference of speed over cost and quality, and the balance of project managers among project scope, budget and resource available. A study conducted in Nigeria showed severe delay in construction projects (Luka and Muhammad, 2014). Similar study conducted in Zambia road construction identified fourteen major causes of schedule variation Chabota et al. (2008).

Effective time control is challenged by different factors. According to Olawale and Sun, 2010, the top five factors inhibiting effective project time control in descending order are: design changes, inaccurate evaluation of projects time/duration, complexity of works, risk and uncertainty associated with projects and ill-performance of subcontractors and nominated suppliers. Likewise, Kasimu and Abubakar (2012) conducted delay study in the Nigerian construction industry and identified the top five factors that influence delay in ascending order as improper planning, lack of effective communication, design errors, shortage of supply like steel, concrete and slow decision making.

Mengistu (2010) showed that project controlling supportive techniques and software are not applied well for the control of actual and planned activities in the Ethiopia construction sector and recommends the significance of training requirement for the concerned project staff. Similarly, Abadir (2011), found out that among the knowledge areas of project in Ethiopia, project time management is considered the critical one with only $24 \%$ projects managed well.

\subsection{The Ethiopian Construction Sector}

Currently, Ethiopia is in a struggle to undertake mega projects that demands huge finance and political decisions. At the moment, this idealistic view is becoming reality guaranteed by the nation's dedication and ability to fund major projects from domestic sources. This has resulted in astonishing growth trajectory whereby the average GDP growth of 11 percent over the past 8 years has been achieved
(MoFED, 2013). The construction sector in Ethiopia is booming and still continuing to have a leading part in the industry.

The fast growth of the construction industry resulted in increased in the number of contractors joining the industry. During the period 2000 up to 2008, the number of contractors increased by $1.912^{1}$. Consequently, there are a total of 7259 building contractors (BC), road contractors (RC) and general contractors (GC) registered during the 2014/15 budget year as implied by the Ministry of Urban Development, Housing and Construction of Construction Industry Development and Regulatory Bureau. The numbers of larger contractors up to level three are: $263 \mathrm{BC} 1 / \mathrm{RC} 1 / \mathrm{GC} 1 ; 73 \mathrm{BC} 2 / \mathrm{RC} 2 / \mathrm{GC} 2 ; 163$ $\mathrm{BC} 3 / \mathrm{RC} 3 / \mathrm{GC} 3$.

Considering the high role of the construction sector in the industry and the demand to participate more contractors in the sector, the former Ministry of Urban Development and Construction revised its guideline and developed the "Amended Directives for the registration of Construction Professionals and Contractors No. 23/2013". On top of the private sector, authorities and government agencies are involved in construction of infrastructures by employing inhouse advisors. As a result, considerable numbers of expertise were employed. Nevertheless, the construction work performance in building construction does not progress as it was supposed to be within the last 50 years (ECIDP, 2014).

\section{Research Design and Methodology}

This research adopts a combination of both quantitative and qualitative methods. The primary data were obtained with the use of structured questionnaires (quantitative) and selected interviews (qualitative) for possible mitigation measures. The combination of quantitative with qualitative methods of data collection in research has become a common practice in recent years for greater understanding and validation of results (Bryman, 2006).

\subsection{Sample Size and Sampling}

\subsubsection{Sampling Size}

Considering the homogeneity of the construction sector from grade one to three in terms of formulation and category, convenient sampling was adopted for pilot and final questionnaire distribution. According to the Ministry of urban development and housing construction website (www.MoUDHC.gov.et) the current grade one to three general, building and road contractors in the country are 499 .

$$
n_{0}=\frac{Z^{2} P(1-P) N}{Z^{2} P(1-P)+\mathrm{Ne}^{2}}
$$

Formula 1 has been used to determine the sample size. Where: $\mathrm{n}_{\mathrm{o}}$ is sample size, $\mathrm{z}$ is confidence interval corresponding to a level of confidence; $\mathrm{p}$ is population proportion; $\mathrm{N}$ is population size and $\mathrm{e}$ is precision or error

1www.mwud.gov.et accessed on March 2, 2014. 
limit. Hence, by considering the value of $(\mathrm{N})$ equals to 499 , $\mathrm{Z}=1.96 \quad(95 \%$ Confidence Interval), $\mathrm{p}=0.5$ and level precession $\mathrm{e}=10 \%$, and the result revealed sample size of 80 (Yamane, 1967: 258).

Again, taking Yamane (1967: 258) formula for determining the required response rate for the amount of sample size determined, the researcher used the following method of determination.

$$
\mathrm{r}=\frac{\mathrm{n}}{1+\mathrm{ne}^{2}}
$$

In Formula 2, Where: $\mathrm{n}$ is sample size; $\mathrm{r}$ is required responses and $\mathrm{e}^{2}$ represents error limit or the level of precision of $10 \%$. Accordingly, by assuming response rate of $56 \%$ the sample size to be distributed was identified as 130 for the contractors and finally able to achieve $75.4 \%$ of response rate.

\subsubsection{Sampling}

The study was conducted in four stages: first to identify common techniques and software packages used for project time control and delay causing factors; second to access the level of techniques and software packages used for project time control, third to rank factors affecting delay in construction projects in Ethiopia from various stakeholders (consultant, contractor, client, and other engineering professionals) perspective; and lastly to identify possible mitigation measures for delay in construction projects.

The factors in the questionnaire including techniques of time control and time delay factors was identified by conducting detailed literature review Accordingly, different factors were tabulated in the questionnaire for respondents to rate. Table 1 below shows different time delay factors extracted and combined from different literatures to serve as a structured questioner to rank the factors affecting project delay in the Ethiopian construction sector. The list is classified into four categories: factors related to construction item; factors related to project participant; environmental factors and financing factors (Luka and Muhammad, 2014; Ibrahim and Nabil, 2013; Mahamid and Amund, 2012; Abadir, 2011; Ali and Kamaruzzaman, 2010; Olawale and Sun, 2010; Azhar et al, 2008; Chabota et al., 2008 and Nega, 2008).

Table 1. List of time delay factors extracted from different literatures.

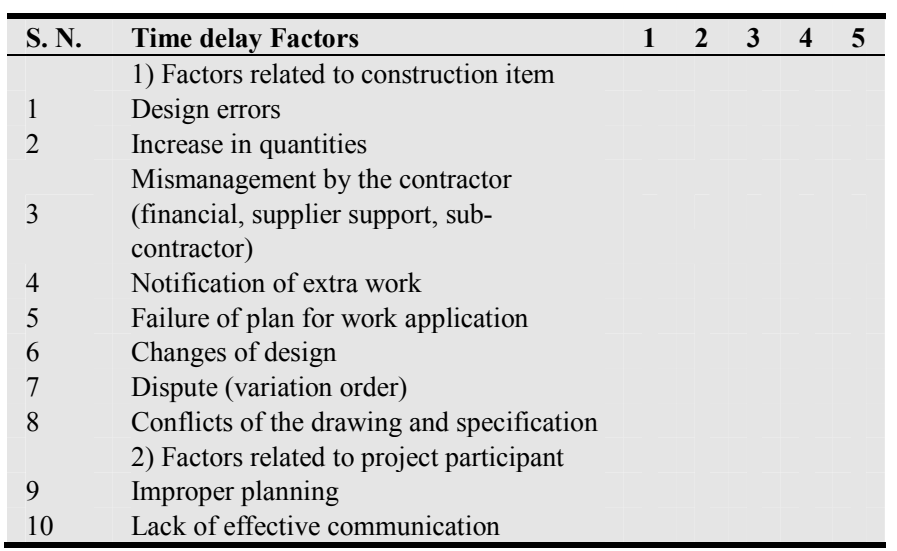

\begin{tabular}{|c|c|c|c|c|c|c|}
\hline S. $\mathbf{N}$. & Time delay Factors & 1 & 2 & 3 & 4 & 5 \\
\hline 11 & Slow decision making & & & & & \\
\hline 12 & $\begin{array}{l}\text { Executive bureaucracy in the owners' } \\
\text { organizations }\end{array}$ & & & & & \\
\hline 13 & Changes in site conditions & & & & & \\
\hline 14 & $\begin{array}{l}\text { Contractors regarded contractual } \\
\text { relationships }\end{array}$ & & & & & \\
\hline 15 & $\begin{array}{l}\text { Late confirmation from client and } \\
\text { consultant regarding cost, quality and time }\end{array}$ & & & & & \\
\hline 16 & Experience of project team & & & & & \\
\hline 17 & Quality assurance / control & & & & & \\
\hline 18 & $\begin{array}{l}\text { Long period for approval of tests and } \\
\text { inspections }\end{array}$ & & & & & \\
\hline 19 & Project management issues & & & & & \\
\hline 20 & Negligence & & & & & \\
\hline 21 & $\begin{array}{l}\text { Late deliveries of materials and } \\
\text { equipments }\end{array}$ & & & & & \\
\hline 22 & Negotiation during construction & & & & & \\
\hline 23 & Mistakes during construction & & & & & \\
\hline 24 & $\begin{array}{l}\text { Changed orders and mistakes and } \\
\text { discrepancies in contract documents }\end{array}$ & & & & & \\
\hline 25 & $\begin{array}{l}\text { Conflicts in work schedules of } \\
\text { subcontractors } \\
\text { 3) Environmental factors }\end{array}$ & & & & & \\
\hline 26 & Shortage of supply like steel, concrete & & & & & \\
\hline 27 & Shortage of material & & & & & \\
\hline 28 & Date of notice to proceed & & & & & \\
\hline 29 & Indicative of experiences & & & & & \\
\hline 30 & Political influence & & & & & \\
\hline 31 & Social influence (feedback from resident) & & & & & \\
\hline 32 & Site accidents & & & & & \\
\hline 33 & Economic conditions & & & & & \\
\hline 34 & User changes & & & & & \\
\hline 35 & Designers & & & & & \\
\hline 36 & Possible prejudices & & & & & \\
\hline 37 & Religions factors & & & & & \\
\hline 38 & Weather condition (Force-Marjue) & & & & & \\
\hline & 4) Financing factors & & & & & \\
\hline 39 & Cash-flow problems during construction & & & & & \\
\hline 40 & Payment for completed works & & & & & \\
\hline 41 & Liquated damage & & & & & \\
\hline
\end{tabular}

$1=$ very little; $2=$ little; $3=$ moderate; $4=$ high and $5=$ very high

For the survey, pretested questionnaire was developed to assess factors for project delay. Pilot questionnaires were sent to 10 professionals for their comment and adjustment. Their comments and inputs were incorporated in development of the final questionnaire that was distributed and collected. Key informant interviews was conducted using semistructured questions ten senior professionals in the construction sector with the objective of pointing out possible solutions for the top selected challenges identified through the survey. These professionals were identified through thorough discussions with associations and contractors, and also through snowball technique by asking the selected respondents to recommend others.

\subsection{Data Analysis and Interpretation}

The data collected through pre-tested structured questionnaire were categorized and analyzed. The data were analyzed and interpreted using SPSS version 20. The fivepoint scale was converted to a Relative Importance Index (RII) for each individual factor using the following formula: 
Relative Importance Index (RII) $=\Sigma \mathrm{w} \div(\mathrm{H} \times \mathrm{N})$

Where, $\mathrm{w}$ is the total weight given to each factor by the respondents, which ranges from 1 to 5 and is calculated by an addition of the various weightings given to a factor by the entire respondent, $\mathrm{H}$ is the highest ranking available (i.e. 5 in this case) and $\mathrm{N}$ is the total number of respondents that have answered the question. Finally, statistical test was conducted on time control ranking agreement or disagreement among the respondents (mainly contractor, consultant and client) with the help of spearman rank correlation coefficient for the research hypothesis.

\section{Result and Discussion}

This section presents the result and discussion regarding the level of techniques and software packages used for project time control, delay in the construction sector and their mitigation measures.

\subsection{Characteristics and Profiles of Respondents}

The respondents were categorized mainly into three groups, namely contractors, consultants and clients which are implementing agencies and financiers.

Table 2. Response rate of the structured questionnaire.

\begin{tabular}{lllll}
\hline Group & Distributed & Returned & Valid & $\begin{array}{l}\text { Valid among distributed } \\
\text { in percentage }\end{array}$ \\
\hline Contractors & 130 & 104 & 98 & 75.4 \\
Consultants & 60 & 33 & 26 & 43.3 \\
Clients & 40 & 24 & 16 & 40.0 \\
\hline
\end{tabular}

Table 2 above indicate that the response rate for the questionnaire survey for contractors, consultants and clients are $75.4 \%, 43.3 \%$ and $40.0 \%$, respectively. According to Sekaran (2001), a response rate of $30 \%$ is acceptable for most studies. Therefore, as the response rate of this study is more than what is referred as adequate by Sekaran (2001), the response rate was considered adequate for the study.

The academic qualifications of the respondents were assessed. Accordingly, out of 140 participants, 18, 78 and 44 of the respondents have Diploma, Bachelor Degree and Masters Degree in engineering, respectively. The education qualifications of the respondents suggest sufficient educational qualification to make the information acquired reliable (Figure 1).

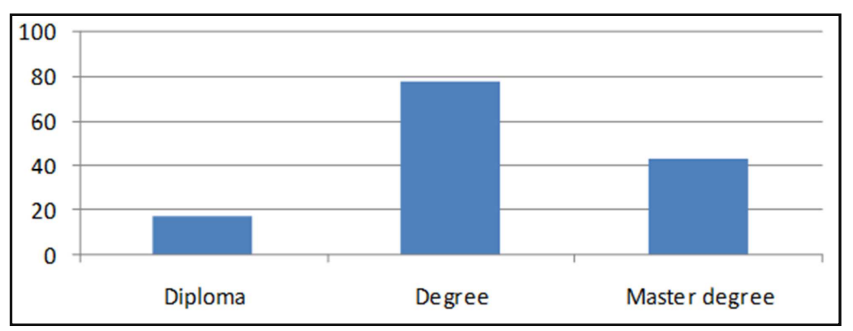

Figure 1. Academic qualifications of respondents.

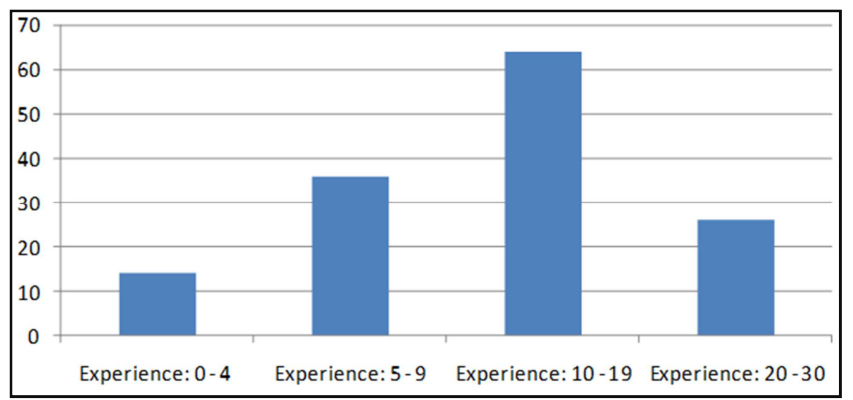

Figure 2. Total work experience of the respondents in the construction sector (in years).

With regard to work experience of respondents, the data implies that out of the total 140 respondents $60,46,26$ and 6 of the respondents have experiences in their current company from 0 to 4,5 to 9,10 to 19 and 20 to 30 years, respectively. Then again, respondents were requested of their years of experience in the construction sector. The response indicated that out of the total 140 respondents, 14, 36, 64 and 26 of the respondents have 0 to 4,5 to 9,10 to 19 and 20 to 30 years, respectively. The profile and experience of the respondents suggest sufficient exposure to make the information acquired reliable (Figure 2).

\subsection{Level of Techniques and Software Packages Used for Project Time Control}

Table 3. Techniques and Software Packages used for planning and time Control.

\begin{tabular}{|c|c|c|c|c|c|}
\hline \multirow{2}{*}{ Techniques } & \multicolumn{2}{|c|}{ Contractors } & \multirow{2}{*}{ Software packages } & \multicolumn{2}{|c|}{ Contractors } \\
\hline & Count & Percentage & & Count & Percentage \\
\hline Gantt Bar Chart & 82 & 83.67 & Microsoft Excel & 86 & 87.76 \\
\hline Milestone Date Programming Technique & 32 & 32.65 & Primavera & 38 & 38.78 \\
\hline Program Evaluation and Review Technique (PERT) & 38 & 38.78 & Asta Power Project & 2 & 2.04 \\
\hline Elemental Trend Analysis/Line of Balance & 18 & 18.37 & Project Commander & 4 & 4.08 \\
\hline Simulation & 10 & 10.20 & & & \\
\hline
\end{tabular}

The analysis indicates that majority of the contractors use Gantt Bar Chart (83.67\%) and Critical Path Networks/Techniques (CPM) (61.22\%) for project planning and time control. On the other hand, majority of the contractors use only two softwares named Microsoft Excel (87.76\%) and Microsoft Project (75.51) for project planning and time control. For the other types of techniques and software, the responses were below $50 \%$ (Table 3). Hence, 
the data show that only few techniques and software packages are being used for planning and time control. The study highlights the importance of conducting training for the concerned staff on the different techniques and software packages very crucial for planning and time control of construction projects.

\subsection{Respondents' Ranking of Factors Causing Delay of Construction Projects}

The respondents were asked to rate with likert scale for factors causing delay on construction projects. The responses were collected with the help of structured questioner of 41 delay factors extracted from literatures classified into four categories. Before further discussion of the results, the correlation between the replies of contractors, consultants and clients are analyzed as follows.

\subsubsection{Hypotheses Testing Results for Delay Factors}

For the assessment of correlation between contractors, consultants and clients response on ranked delay factors, the hypotheses checkup is as follow:

Table 4. Delay Factors Response Correlation between Contractors, Consultants and Clients (Spearman rank correlation, $r$ ).

\begin{tabular}{llll}
\hline & Contractors & Consultants & Clients \\
\hline Contractors & 1 & 0.753 & 0.783 \\
Consultants & 0.753 & 1 & 0.701 \\
Clients & 0.783 & 0.701 & 1 \\
\hline
\end{tabular}

\section{Hypothesis 1:}

$\mathrm{H} 0=$ There is no association between the responses of contractors and consultants for delay factors.

$\mathrm{H} 1=$ There is an association between the responses of contractors and consultants for delay factors.

Results displayed in Table 4 above, $r=0.753$, showed strong correlation between contractors and consultants responses for delay factors ranking. From the above stated facts, it can be seen that the null hypothesis is rejected and $\mathrm{H} 1$ is accepted.

Hypothesis 2:

$\mathrm{H} 0=$ There is no association between the responses of the contractors and clients for delay factors.

$\mathrm{H} 1=$ There is an association between the responses of the contractors and clients for delay factors.

From the result displayed in table 4 above, where $r=0.783$, it shows the existence of positive linear correlation. As a result, the null hypothesis is rejected and $\mathrm{H} 1$ is accepted.

Hypothesis 3:

$\mathrm{H} 0=$ There is no association between the responses of the consultants and clients for delay factors.

$\mathrm{H} 1=$ There is an association between the responses of the consultants and clients for delay factors.

As displayed in table 4 above, where $r=0.701$, it shows the existence of strong positive linear correlation. As a result, the null hypothesis is rejected and H1 is accepted. The result of spearman coefficient between contractors and clients, clients and consultants, and contractors and consultants is $0.78,0.70$, and 0.75 , respectively. The result of spearman rank correlation coefficient for delay factors shows a higher correlation among the respondents. The result of this study shows a better correlation than the finding of spearman coefficient by Abd et al., (2008) where the results are between contractors and clients, clients and consultants, and contractors and consultants of $0.47,0.65$, and 0.69 , respectively.

\subsubsection{Time Delay Factors}

The contractor is the primary responsible body especially in the case of unjustifiable delays and incurs pressure, even if it is justifiable delay. As per the contractors' response, the top five factors identified to result in delay of construction projects are cash flow problem during construction (3.82), mismanagement by the contractors (3.78), improper planning (3.73), slow decision making (3.67) and late delivery of material and equipment (3.55) (Figure 3 and Table 5). On the other hand, the top five factors as per the consultants and clients responses are ranged between medium to very high and high to very high, respectively.

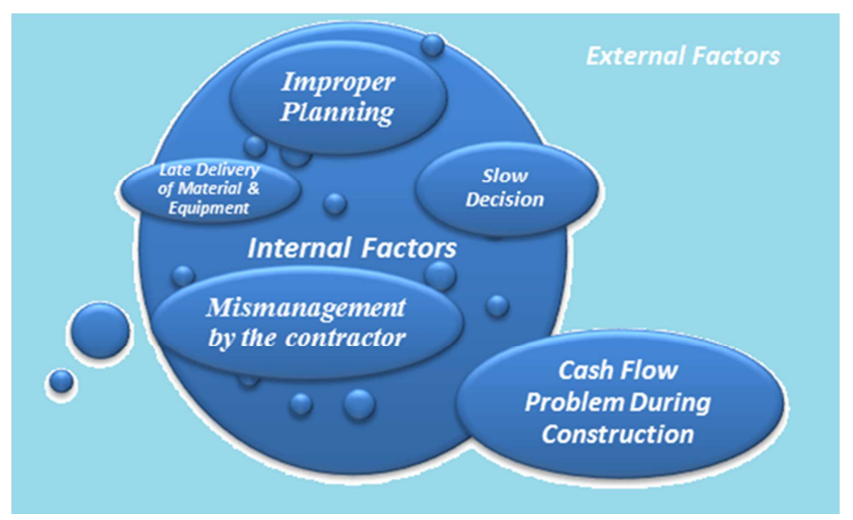

Figure 3. Top Five Internal and External Factors Contributing to Delay in Ethiopian Construction Sector.

\section{Cash Flow Problems During Construction}

The contractors rank cash flow problems during construction grouped under financial factors as the first time delay factor. Cash flow problems include the difficulty to get working capital and the challenge to provide competitive credit to suppliers and sub-contractors. In agreement with these, Chabota et al. (2008) who studied the Zambian road construction sector revealed that protracted financial processes $(67 \%)$ and financial difficulties $(60 \%)$ are ranked $2^{\text {nd }}$ and $3^{\text {rd }}$ out of 14 major causes of delay. Due to the existence of financial problem, the delay in payment (which is ranked as $10^{\text {th }}$ by the contractors) shows the extent of the challenge. The response for delay of construction projects due to cash flow problem during construction is ranked as $17^{\text {th }}$ and $6^{\text {th }}$ by the consultants and clients, respectively. The clients' response is in line with the contractors; however, the consultants' response is different from the contractors where, the consultants associated the cash shortage with mismanagement, as they ranked the mismanagement second delay factor. Similarly, Chabota et al. (2008) study in Zambia implies delayed payment (75\%) is ranked $1^{\text {st }}$ out of 14 major causes of delay. Another study by Abd et al. (2008) show financing by contractors and delay in 
payment are ranked $1^{\text {st }}$ and $2^{\text {nd }}$ out of 32 factors for building projects in Egypt.

\section{Mismanagement by the Contractors}

The contractors' response shows that the existence of mismanagement (financial, supplier support, sub-contractor) ranked as the $2^{\text {nd }}$ reason for delay of construction projects. In this regard, the response of the consultants and clients ranked as $2^{\text {nd }}(4.31)$ and $3^{\text {rd }}(4.13)$, respectively, which show the contractors responsibility to manage projects appropriately. This is partly related to the limited use of software and techniques for project follow-up by contractors (Table 3). The scenario is similar in Zambia where poor coordination on site is ranked among the 14 major causes of delay in road construction (Chabota et al., 2008).

\section{Improper Planning}

The contractors' ranked improper planning as the $3^{\text {rd }}$ cause for construction delay. This is even perceived more by the consultants and clients who ranked as $1^{\text {st }}(4.54)$ and $2^{\text {nd }}$ (4.38), respectively. This justifies

that less utilization of software packages and techniques available for managing projects leading to mismanagement of resources (Table 3 and 5). Idle resources on site mostly result in a huge expense and could end up in severe cash shortage, even loss. Supporting this argument, Olawale and Sun (2010) explained inaccurate evaluation of projects duration is the $2^{\text {nd }}$ most important factors inhibiting effective project time control. Similarly, Kasimu and Abubakar (2012) argued that improper planning is $1^{\text {st }}$ out of 43 factors causing delay in the Nigerian construction sector and Bertin (2011)'s study in Cameroon showed lack of project planning is ranked in the top three important causes of time delay.

\section{Slow Decision Making}

Slow decision making is ranked $4^{\text {th }}$ important factor for delay of construction projects. Consultants have similarly responded. However, the clients ranked as $19^{\text {th }}$ factor (3.25). With regard to the causes for slow decision making, key informant interview conducted revealed that the slow decision making is associated with lack of information. Slow decision making is ranked the $5^{\text {th }}$ out of 43 factors in the Nigerian construction sector whereas $8^{\text {th }}$ of the 32 factors for building projects in Egypt (Abd et al., 2008; Kasimu and Abubakar, 2012).

\section{Late Delivery of Material and Equipment}

Late delivery of material and equipment is ranked as the $5^{\text {th }}$ factor for delay of construction projects by the contractors. In this regard, the consultants and clients ranked as $6^{\text {th }}(\mathrm{M}=3.92)$ and $3^{\text {rd }}(\mathrm{M}=4.13)$, respectively. In line with this, the study of Chabota et al., (2008) shows late material procurement and equipment unavailability is the major cause of schedule delay. The contractor is responsible to implement proper tools, techniques and personnel for effective planning and management of resources. Moreover, the contractor should implement knowledge management system for making quick quality decision. The finance and cash flow problem during construction could be solved by the joint work of the contractor as well as the support of the regulatory body. The stakeholders involved can effect payment on time when there is an arrangement of a financial system for advancing working capital. At the same time, the contractor's application of strict cost management on a project can minimize the burden. Besides, the habit of outsourcing shall be enhanced in order to enable the contractor to avoid extra overhead expense at idle time. The application of mitigating measures such as preventive, predictive, corrective and organizational natures can help to minimize or avoid delay.

Table 5. Contractors Response for Time Delay Factors.

\begin{tabular}{|c|c|c|}
\hline No. & Contractors Response of Time Delay Factors & RII \\
\hline 1 & Cash-flow problems during construction & 3.82 \\
\hline 2 & $\begin{array}{l}\text { Mismanagement by the contractor (financial, supplier } \\
\text { support, sub-contractor) }\end{array}$ & 3.78 \\
\hline 3 & Improper planning & 3.73 \\
\hline 4 & Slow decision making & 3.67 \\
\hline 5 & Late deliveries of materials and equipment & 3.55 \\
\hline 6 & Shortage of supply like steel, concrete & 3.53 \\
\hline 7 & Shortage of material & 3.51 \\
\hline 8 & Project management issues & 3.39 \\
\hline 9 & Payment for completed works & 3.39 \\
\hline 10 & Lack of effective communication & 3.29 \\
\hline 11 & Design errors & 3.29 \\
\hline 12 & Executive bureaucracy in the owners' organizations & 3.16 \\
\hline 13 & Increase in quantities & 3.12 \\
\hline 14 & Changes of design & 3.12 \\
\hline 15 & Economic conditions & 3.08 \\
\hline 16 & $\begin{array}{l}\text { Late confirmation from client and consultant regarding } \\
\text { cost, quality and time }\end{array}$ & 2.96 \\
\hline 17 & $\begin{array}{l}\text { Changed orders and mistakes and discrepancies in contract } \\
\text { documents }\end{array}$ & 2.94 \\
\hline 18 & Experience of project team & 2.94 \\
\hline 19 & Failure of plan for work application & 2.92 \\
\hline 20 & Indicative of experiences & 2.90 \\
\hline 21 & Conflicts of the drawing and specification & 2.88 \\
\hline 22 & Quality assurance / control & 2.84 \\
\hline 23 & Long period for approval of tests and inspections & 2.82 \\
\hline 24 & Dispute (variation order) & 2.82 \\
\hline 25 & Contractors regarded contractual relationships & 2.73 \\
\hline 26 & Weather condition (Force-Marjue) & 2.73 \\
\hline 27 & Notification of extra work & 2.73 \\
\hline 28 & Conflicts in work schedules of subcontractors & 2.65 \\
\hline 29 & Designers & 2.59 \\
\hline 30 & Negligence & 2.55 \\
\hline 31 & Mistakes during construction & 2.53 \\
\hline 32 & Changes in site conditions & 2.49 \\
\hline 33 & User changes & 2.49 \\
\hline 34 & Social influence (feedback from resident) & 2.31 \\
\hline 35 & Liquated damage & 2.27 \\
\hline 36 & Possible prejudices & 2.24 \\
\hline 37 & Negotiation during construction & 2.24 \\
\hline 38 & Political influence & 2.22 \\
\hline 39 & Date of notice to proceed & 2.20 \\
\hline 40 & Religions factors & 2.00 \\
\hline 41 & Site accidents & 1.94 \\
\hline
\end{tabular}

\subsection{Mitigation Measures for Time Delay}

The qualitative data collected through key informant interviews using semi-structured question guide was meant to make suggestions for mitigating time delay factors discussed above. Accordingly, data were collected from ten senior 
professionals (engineers) in the construction sector (see Table 6). Following the identification of top five delay factors among the 41 factors, the mitigation measures to minimize and control the effect were sought for the top five factors. The top five factors were considered highly important as shown by the mean of the responses of the contractors.

Table 6. Profile of key informant interviewees.

\begin{tabular}{|c|c|c|c|c|c|}
\hline Position & $\begin{array}{l}\text { Total Experience } \\
\text { (years) }\end{array}$ & $\begin{array}{l}\text { Interview } \\
\text { duration (hrs) }\end{array}$ & Position & $\begin{array}{l}\text { Total Experience } \\
\text { (years) }\end{array}$ & $\begin{array}{l}\text { Interview } \\
\text { duration (hrs) }\end{array}$ \\
\hline Technical Manager & 18 & 1.35 & General Manager & $>30$ & 1.20 \\
\hline $\begin{array}{l}\text { Managing director (Structural } \\
\text { Engineer) }\end{array}$ & 17 & 1.35 & $\begin{array}{l}\text { Constrcution and Real Estate } \\
\text { developer (CEO); }\end{array}$ & $>30$ & 1.20 \\
\hline $\begin{array}{l}\text { Consult (Senior Structural) } \\
\text { Engineer) }\end{array}$ & 13 & 1.25 & General Manager & $>30$ & 1.50 \\
\hline Senior Project Manager & $>30$ & 1.35 & Assistant professor and consultant & $>30$ & 1.10 \\
\hline
\end{tabular}

\subsubsection{Mitigation Measures for Cash Flow Problem During Construction}

The responsibility of contractors for finishing the job within the budget, time and quality is agreed by all the respondents. It is also pointed out that the contractor has the right to cease projects when contractual obligations are not met by the other party (MoWUD, 1994; PPA, 2011). However, to stop the job on time is challenging since it is difficult to get another work to shift the resources. Demobilizing idle resources is also very challenging. There a thin line between ceasing and continuing the work due to the high overhead of the companies.

All of the respondents argued that most of the contractors are investing the advance payment on assets (car, house, other business, etc.) and/or even on other projects. Sometimes contractors are participating and winning projects for the sake of securing advance money to solve issues unrelated to the project. The respondents also pointed out that lack of proper financial personnel results in long-term financial crises. Among the major mentioned factors lack of claim preparation and realistic priced BoQ and timely preparation of error free payment certificate. The challenge to get project finance such as working capital put a burden on the contractor. As a result, most of the contractors submit credit line facility during tender. However, in reality to get the same working capital during the execution of the work is very rare. Hence, facilitation shall be done for its practicality. The scarcity of suppliers who can provide valid receipt makes even difficult to report the expense which in return depreciate the profit. Besides, the supplier or sub-contractor who can provide on a credit base is very minimal. Hence, it is recommended that the contractor has to ask and check in advance the availability of the finance in the client account and ask late payment with interest, employ competitive experts for financial management, scheduling and claim compilation and shall perform cash flow problem prediction with possible way out with the help of knowledge management system. Moreover, instead of utilizing project cash for other purpose, it is better for the contractor to plan a mechanism to find external legal financial source or raise money, proper utilization of advance money and interim payments, involve in related investment for quick money generation without touching project finance and in advance plan for sharing/minimizing risk.

Ones more, the contractors shall give emphasis on payment collection and if needed to dedicate one department for timely preparation of error free payment certificate, to compile claim timely and to make quick correction on payment certificate. Furthermore, empowering projects to plan and allow deciding on the cash flow instead of centralized system will add to the solution. The contractors should identify potential items in advance to be subcontracted and sign memorandum with supplier and subcontractors for sharing risk.

In time of financial burden, the client has to be willing to assist the contractor by procuring material, fuel, salary, material rent, and wedge payment by analyzing cash flow disbursement. Delay on payment creates a burden, hence, when certifying payment requires more time, commitment of consultant and client to advance payment on visual inspection could lower the burden. Accordingly, the banking sector has to practice to give payment guarantee and pay in case of late payment.

Moreover, the government authority has to formulate guide in order to consider bank or insurance guarantee instead of cash retention $(2.5 \%$ to $5 \%$ of work executed) by client. If not, to keep the retention money in a closed account for ease of obtaining by the contractor up on final acceptance of the project.

Clients, furthermore, have to secure project budget and monitor payment indirectly, even to the extent of paying part of advance payment directly to potential suppliers and releasing another advance especially for high cost finishing work items when it needs more money. They should as well avoid awarding to very low price bid or to create a mechanism to adjust bid price to the engineering estimate. The authority has to create separate institutions who can register potential stakeholders who can provide material, equipment and machinery suppliers for the provision of credit for the contractor. Facilitation of database for national material source location and perform cost consideration of items that might lack full receipt could further be done. Moreover, they should analyze claim and effect payment, for the approved part, within a couple of weeks/months. Considering the scarcity of claim experts in the construction 
field, special aid shall be given by the concerned authority on how to compile claim especially for works done jointly or as a sub-contract with international contractors.

The clients, associations, universities, authority and consultants jointly has to work to provide central data management system by the authority for ease of contractors to trace the trend as well as real time data in the country. They should further work towards incorporating financial management and law courses for engineering undergraduate education curriculum of the country and establishing an organization that can assist the contractors during project management so as to minimize the knowledge gap.

\subsubsection{Mitigation Measures for Poor Planning and Mismanagement by the Contractor}

In general, all the respondents agreed that the scope of planning in the construction sector is small and shall be given emphasis. Since planning and monitoring is critical for project success, it is mandatory to prepare material, equipment, labor and cash flow plan. The response from respondents implied that plan shall be integral part and shall be done at the initiation, during and final stage of the project by all stakeholders of the project. Accordingly, the purchasing and supply department shall prepare a joint procurement plan which goes with the master schedule for stating the source, location, transport, delivery time, cost and alternatives. To support this, the human resource department has to hire carefully competent personnel, perform capacity building activities based on need assessment, as well as put an effort to lower the turnover of staff.

The respondents experience in this regard shows that most of the contractors submit project schedule for the sake of submission only. It is implied that some even outsource schedule preparation for professionals who does not have much knowhow of the companies' resource. Some contractors outsource activities when they face challenges related with time or cost; others outsource some works which are not justified for the reason doing so. Notifying the subcontractors in advance and integrate their schedule with the master schedule shall also be done. Contractors could sign in advance memorandum of understanding with potential suppliers to save time, cost and maintain quality of work.

Respondents furthermore pointed out the fact that there are considerable numbers of contractors who acquired their license without fulfilling the minimum requirement of personnel and machinery, with sold or lost asset, improper initial document and/or acquired outdated resources required by the authority. This in turn leads to lower competitiveness of the contractor to manage the project. This problem can be addressed by the authority through assessing the current status of contractors and check the viability of existing qualification criteria. It is also advised to take measures against those contractors (such as confiscation of their license) who do not satisfy the minimum requirements in the areas of human resource, equipment and machineries.

In the case of contractors, it is suggested in the first place to acquire appropriate professionals with the right knowledge and skill. Enhancing the capacity of staff to use modern techniques of project planning should be part of their routine. Taking such actions would enable contractors to attain updates on contract documents; terms, specifications and drawings; to ask for clarification; to prepare and update detailed proper schedule and contingency plan and to conduct proper project performance evaluation and monitoring system. This way it is possible to efficiently and effectively utilize resources, arrange a system to receive and analyze weekly cost, scope and delay variance from projects, and plan timely mitigation measures. In addition, it is advised that the contractor has to formulate specific methodology for each project depending on the context and train workers accordingly instead of adopting one fit methodology for all. This should be coupled with allocation of the right type of resources at the right time and location, and adoption of the right type of software and techniques.

The respondents further underlined that delegation of responsibility and authority is very vital for projects success. This would make timely quality decision regarding the management of resources and reduce dependence on head office managers and/or the company owner. Contractors are further advised to apply performance based promotions and incentives to workers rather than personal affiliations. The delegated project manager or responsible person should be obligated to prepare and analyze weekly detailed actual expense (cost), contractual cost and revenue of the project with challenges and possible solutions.

With regard to challenges due to external factors, the respondents explained that such challenges are often resulted from negligence by the consultant, unforeseen works and/or ambiguity on specification and design. One reason for this could be the small fee paid to consultants which causes shallow work done. It is recommended that works has to be done towards re-engineer most of the clients' perspective to believe in professional works.

The key informant interviews also highlighted that mismanagement of resources are caused by two factors: lack of knowledge and due to theft. Both problems can be managed by proper planning. Lack of knowledge can be addressed by adopting appropriate methodology and enhancing capacity of staff. On the other hand, theft can be controlled well with the help of project based planning and communications with appropriate tools like Enterprise Resource Planning (ERP).

Government could also aid stakeholders by facilitating credit facility for the provision of adequate equipment and resources; implement central knowledge management system to keep records of materials including quarry sites, regional labor index and potential suppliers of machinery with relevant data like cost, and output.

\subsubsection{Mitigation Measures for Slow Decision Making, Late Delivery of Material and Equipment}

The respondents agreed that reactive burden prevention of one project at the expense of other shall be avoided and if one project has to cease due to different reasons, it is better to make 
the bitter decision than letting it survive at the expense of other projects. This is due to the fact that one slippage coming at a time could reach an extent of no turning point. The cumulative effect of slow decision making will shake the company and finally results in its collapse. Hence, decisions shall be made as soon as possible. Quick decision making skill can be achieved by getting trainings on decision making, communication, financial management, and adoption of alternatives approaches and so on. Such trainings are vital for project managers and selected project bodies; hence it should be integrated in a company's human resource development plan.

Contractors should revise design and specification before or after any kind of work and ask for explanation whenever there is ambiguity. They should also propose alternatives ahead of time. The management has to trust professional decisions and avoid emotional action taken by owners and non-technical staffs. Moreover delegating and empowering project managers to manage cash to considerable limit will be beneficial and shorten decision making chains. Consultants, on the other hand, have to design carefully in detail, delegate and employ the appropriate supervisor with relevant experience, knowledge and skill. They should also empower resident engineers (site supervisors). The authority has to promote detail designing, planning and quality work; and set accountability clause for consultants on major deviation of design, specification as well as for slow decision. Most importantly the consultant and client have to work jointly with the contractor to develop a team spirit and own the project for its pain and gain.

\section{Conclusion and Recommendations}

The study implied that the contractors' experience of applying different techniques and software packages for planning and time control is minimal. The low trend in using techniques and software packages application for project planning and time control can be improved by employing capable person, as well as conducting trainings and capacity building activities for the concerned staffs.

The study suggests that measures shall be taken for the top five identified delay causing factors of cash flow problem, mismanagement, improper planning, slow decision making and late delivery of material and equipment. Frequent revision and understanding of schedule shall be performed by the contractor for taking proactive measures. Delay of contractors on project execution can be improved through proactive planning on alternative financial sources, effective and efficient management of resources including appropriate disbursement of advance using cost management, application of timely knowledge based decision, adoption and application of the right methodology and resource at the right time and right place. Besides, contractors should plan and negotiate in advance with reliable sub-contractor and/or supplier on the outsourced items. Universities and Contractor and Consultant Associations should conduct intensive training and public discussion forums for all professionals in the sector on the approaches to address the aforementioned delay factors. Moreover, clients and government should work on mechanisms to attract capable professionals and work jointly with the associations and universities. The relationship between consultants and clients towards the contractors should be based on mutual trust. Such kind of relationship prevents the work from suffering. The Government shall come with legal clauses on substitution of liquid retention money with bond, provision of accessible resource data base and record of best practice. Government should further create an organization that can assist contractors during project management complications. It should attain more acknowledgment and promotion to professionals, work on a mechanism to adjust proportional fee to consultants, and set accountable clause for consultants on major deviation of design, specification and for slow decision, create transparent way to check existence of cash for the project and provision of working capital for the contractors during tight budget needs.

\section{Suggestions for Further Research}

This study mainly focused on the current delay of the construction projects. Hence future studies on delay causing factors could be done constantly with their mitigation measures. Similar study could also be conducted in other countries to see cross country comparison and to have a more global view of delay factors in the construction sector. Specific studies in specific projects that experienced significant delay could also be conducted using similar approaches used in the current study. Further study on ranking the survey responses by profession and by sector may result in interesting discoveries. Also studies based on project size and duration may result in remarkable findings.

\section{References}

[1] Abadir, H. and Yimam. (2011) Project Management Maturity in the Construction Industry of Developing Countries (The Case of Ethiopian Contractors). M. Sc. Thesis, University of Maryland, USA.

[2] Abd E. R., Bassioni, H. and Mobarak, A. (2008) Causes of delay in building construction projects in Egypt. Journal of Construction Engineering and Management, 134 (11) pp. 831841.

[3] Abraham Assefa (2008). Time - Cost Relationships for Public Road Construction Projects in Ethiopia. Master's Thesis, Addis Ababa University.

[4] Ali A. S. and Kamaruzzaman S. N. (2010). Cost performance for building construction projects in klang valley. Journal of Building Performance 1: 1 P110-118.

[5] Azhar, N., Farooqui, R., and Ahmed, S. (2008). Cost Overrun Factors In Construction Industry of Pakistan. Proceedings of the First International Conference on Construction in Developing Countries, Karachi, Pakistan. 
[6] Bertin B. Akoa (2011). Cost Overrun and Time Delays in Highway and Bridge Projects in Developing CountriesExperience from Cameroon. M. Sc. Thesis, Michigan State University, USA.

[7] Bryman, Allan (2006). Integrating quantitative and qualitative research, How is it done? Qualitative research, Vol. 6 (1) 97 113. SAGE Publications, London, Thousand Oaks, CA and New Delhi.

[8] Carey J., (1983). Implementing a standardized planning and control system in the DP environment. Journal of Project Management 1: 4 P 225-229.

[9] Chabota Kaliba, MundiaMuya and Kanyuka Mumba (2008). Cost escalation and schedule delays in road construction projects in Zambia. International Journal of Project Management.

[10] David K. Anderson and Tony Merna (2003). Project Management Strategy project management represented as a process based set of management domains and the consequences for project management strategy. International Journal of Project Management 21 P 387-393. www.elsevier.com/locate/ijproman.

[11] Eric T. G. Wang, Hsiao-Lan Wei, James J. Jiang and Gary Klein, (2006). User diversity impact on project performance in an environment with organizational technology learning and management review processes. International Journal of Project Management 24: P 405-411.

[12] Ethiopian Construction Industry Development Policy (ECIDP) (2014). Approved by Ministry mikir bet, published by December 2014.

[13] Harold Kerzner (2009). Project Management: a system approach to planning, scheduling and controlling, tenth edition. John Wiley \& Sons, Inc., Hoboken, New Jersey.

[14] Ibrahim Mahamid and Nabil Dmaidi (2013). Risks Leading to Cost Overrun in Building Construction from Consultants' Perspective. Organization, technology and management in construction · an International journal 5: 2 P 860-873.

[15] Janice Thomas and Thomas Mengel (2008). Preparing project managers to deal with complexity - Advanced project management education. International Journal of Project Management 26 P 304-315.

[16] Karlos Artto, Jaakko Kujala, Perttu Dietrich and MiiaMartinsuo (2008). What is project strategy? International Journal of Project Management 26: 4-12. Available online at www.sciencedirect.com

[17] Kasimu A. M. and Abubakar D. I. (2012). Causes of delay in Nigeria construction industry. Interdisciplinary journal of contemporary research in business 4: 2 P 785-794.

[18] Larry Rich man (2002). Project Management: Step by Step. AMACOM, a division of American Management Association, NY, USA.

[19] Lars Taxen and Joakim Lillieskold (2008). Images as action instruments in complex projects. International Journal of Project Management 26 P 527-536.

[20] Li-Yin Shen, Andrew Plattenand X. P. Deng (2006). Role of public private partnerships to manage risks in public sector projects in Hong Kong. International Journal of Project Management 24 P 587-594.

[21] Luka Goji Tipili and Muhammad Sa'adiyallyasu (2014).
Evaluating the impact of risk factors on construction projects cost in Nigeria. The International Journal Of Engineering And Science (IJES) 3: 6 P 2319-1805.

[22] Mahamid, I and Amund, B (2012) 'Cost deviation in road construction projects: the case of Palestine'. Australasian Journal of Construction Economics and Building, 12: 1 P 5871.

[23] Mengistu Berhanu, 2010. Project Management Practices. The case of EECMY-DASSC focusing on planning, scheduling and controlling phase. M. B. A. Thesis, Unity university, Ethiopia.

[24] Ministry of Finance and Economic Development (2013). Brief Note on the 2005 (EFY)* GDP Estimates series, http://www.mofed.gov.et/English/Resources/Documents/THE percent202005percent20EFYpercent20GDPpercent20andperc ent20OTHERpercent20RELATEDpercent20MACROECONO MICpercent20INDICATORS.PDF.

[25] Minstry of Works and Urban Development (MoWUD), (1994). Standard conditions of Contract for construction of civil work projects.

[26] Nega, F. (2008). Causes and effects of cost overrun on public building construction projects in Ethiopia. Master thesis, Addis Ababa University, Addis Ababa, Ethiopia.

[27] Olawale, Y., and Sun M. (2010). "Cost and time control of construction projects: Inhibiting factors and mitigating measures in practice." Construction Management and Economics, 28: 5 P 509-526.

[28] Ping Chen a, David Partington, Jia Ning Wang (2008). Conceptual determinants of construction project management competence: A Chinese perspective. International Journal of Project Management 26 P 655-664.

[29] PMI (1996). Project Management Institute. A Guide to the Project Management Body of Knowledge.

[30] Sekaran, U. (2001). Research methods for business: A skills building approach $\left(2^{\text {nd }} E d\right.$.). New York: John Wiley \& Sons, Inc.

[31] UNDP (2014). Ethiopia: quarterly economic brief. Accessed on http://www.et.undp.org/content/dam/ethiopia/docs/Economic \%20Brief-\%20Third\%20Quarter-2014.pdf.

[32] UNDP, (2014). Country Economic Brief: Ethiopia. Accessed on http://www.et.undp.org/content/dam/ethiopia/docs/Country\%2 0Economic\%20Brief\%201\%20final\%20for\%20web.pdf.

[33] Warszawski, A. (1996). "Strategic planning in construction companies." Journal of Construction Engineering and Management, 122: 2 P 133-140.

[34] Weinberg, S. and Abromowitz, S. (2008) Statistics Using SPSS: An Integrative Approach. Cambridge University Press, Cambridge.

[35] Yamane, T. (1967) Statistics: An Introductory Analysis, Harper and Row. 